\title{
APRON ENTRAINMENT AT THE MARGINS OF SUB-POLAR GLACIERS, NORTH-WEST ELLESMERE ISLAND, CANADIAN HIGH ARCTIC
}

\author{
By David J.A. Evans*
}

(Department of Geography, University of Alberta, Edmonton, Alberta T6G 2H4, Canada)

\begin{abstract}
From observations on the sub-polar glaciers of Phillips Inlet, north-west Ellesmere Island, neither complex basal thermal regimes nor internal thrusting need be invoked to explain all types of debris distribution in the basal ice of sub-polar glaciers. Debris is present in the terminal ice cliffs as: (1) debris-poor folia expressing internal flow patterns; (2) debris-rich bands of various thickness; and (3) augens or clots. Debris-rich bands and augens are concentrated predominantly in the basal ice, contain a wide range of grain-sizes, cut across debris-poor folia, rarely extend $>1 \mathrm{~m}$ laterally, and are irregularly spaced.
\end{abstract}

Observations on patterns of entrainment and contemporary processes at ice margins, together with clast-shape analyses, suggest that the recycling and re-incorporation of fluvial/deltaic sediment, aprons, and pro-glacially thrusted blocks at the ice face are an alternative process of debris entrainment to basal plucking and large-scale freeze-on at the base of the glacier. The most active processes observed at the glacier margins are fluvial, and the origins of some debris-rich bands and augens are linked to thermal-erosional niches and abandoned meanders in the base of the glacier cliff face. Because the large-scale accumulation of ice-cored debris at glacier snouts represents periods of increased run-off and snout recession (specifically during the early Holocene), basal and englacial debris concentrations resulting from glacial over-riding and re-incorporation have great palaeoclimatic significance.

\section{INTRODUCTION}

To date, little research has been directed towards the understanding of debris entrainment in high-latitude glaciers. Boulton (1972a, b), using observations on modern Arctic glaciers, suggested that sub-polar and polar glaciers entrain debris by freezing on of material at the transition from warm- to cold-based conditions. Boulton argued that this explains thicker accumulations of basal debris in polar and sub-polar glaciers when compared to temperate glaciers. However, Shaw (1977b) pointed out that Boulton's model refers specifically to maritime Arctic environments such as Spitsbergen and Iceland, and may not be appropriate for arid polar environments. In arid environments, the most effective process of entrainment is frontal apron incorporation, which also results in high debris concentrations in the basal ice layers (Shaw, 1977a). Aprons may contain a variety of material depending upon predominant ice-marginal processes.

For maritime sub-polar glaciers, Dowdeswell (1986) stated that ice in the accumulation zones of tide-water glaciers on southern Baffin Island is at the pressure-melting point. This provides a source of basal melt water for marginal freeze-on and explains why thick sequences of basal debris-rich ice can occur in this area of the Arctic.

* Present address: 2 Somers Road, North Mymms, Hatfield, Hertfordshire AL9 7PX, England.
Lawson (1979) has reached the same conclusions for Matanuska Glacier, Alaska. Similarly, Hambrey and Müller (1978) explained debris-rich layers and ice-cored moraines at the snout of White Glacier on Axel Heiberg Island by the process of freezing-on of debris and upward thrusting of debris-laden ice over clean ice (Weertman, 1961; Boulton, 1972b; Hooke, 1973).

The magnitude and importance of debris entrainment by apron over-riding, as introduced by Shaw (1977a, b), are still imperfectly understood and the few observations that have been made on sub-polar glacier snouts have done little to assess the validity of Shaw's hypothesis. During the summers of 1985-87, field work was undertaken on the Quaternary geology of Phillips Inlet, north-west Ellesmere Island. During this work the author visited the glacier snouts of the area to initiate a preliminary study of glacial geologic processes and to determine Holocene glacier fluctuations. The aims of this research were: (1) to make a preliminary investigation of the distribution and characteristics of debris entrained within the glaciers of north-west Ellesmere Island and to determine specifically the origin of the debris-rich bands and augens which occur predominantly within the basal ice of the glaciers; and (2) to study the nature of ice-marginal accumulations (aprons) and estimate their role in glacial debris entrainment. Observations made during this study on debris patterns in glacier snouts and contemporary pro-glacial processes suggest that marginal melt water, apron accumulation, and pro-glacial thrusting are important factors in glacial debris entrainment in this High Arctic environment. Furthermore, large-scale concentrations of coarse debris relate to periods of climatic amelioration, specifically during the early Holocene, when glacier snouts were behind present margins and partially covered by outwash.

\section{FIELD AREA}

Phillips Inlet is situated at lat. $82^{\circ} \mathrm{N}$. on the north-west coast of Ellesmere Island, N.W.T., Canada (Fig. 1). The coast of northern Ellesmere Island has a largely continental climate as a result of the permanent sea-ice cover of the Arctic Ocean. A net annual water balance close to zero describes a polar desert environment (Bovis and Barry, 1974). Winter-temperature averages have ranged from $-30^{\circ}$ to $-40^{\circ} \mathrm{C}$ (England and others, 1981). During the summer of 1985 , temperatures of $15^{\circ} \mathrm{C}$ were common in Phillips Inlet, while in 1986 and 1987 summer temperatures were rarely above $4^{\circ} \mathrm{C}$. Surface ablation and melt-water generation are largely restricted to the period between mid June and early August. Because of the relative abundance of supraglacial melt water, the glaciers of the field area are classified as sub-polar. A sub-polar glacier is defined as one which is largely frozen to its bed (in places at pressure-melting point) but undergoes surface melting during summer months (cf. Ahlmann, 1935; Paterson, 1981).

Observations were made on a total of 21 glaciers in Phillips Inlet throughout the 1985, 1986, and 1987 summer seasons (Fig. 1). Glaciers 1 and 4 are trunk glaciers; glaciers 


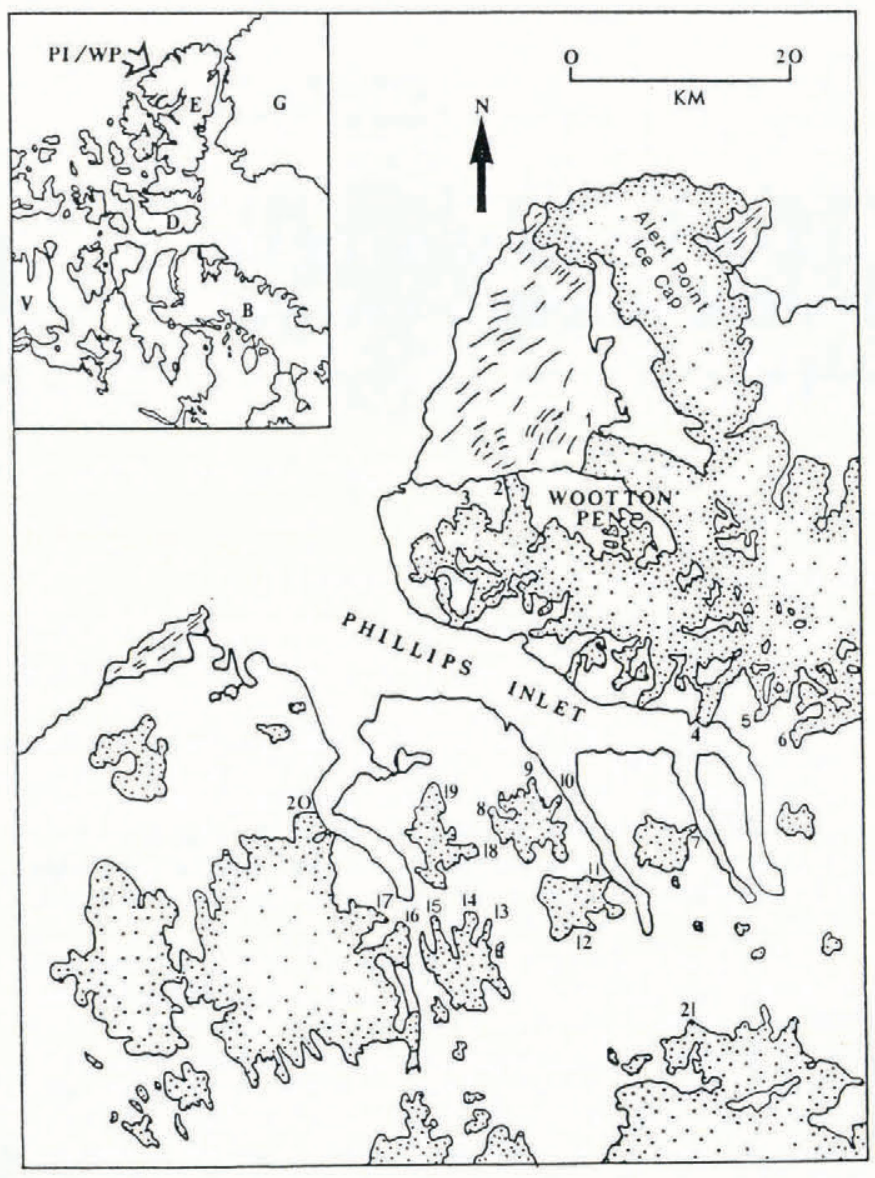

Fig. 1. Location maps of Phillips Inlet and the glaciers studied (labelled 1-21) during the 1985, 1986, and 1987 seasons. E. Ellesmere Island; $G$, Greenland; A, Axel Heiberg Island; D, Devon Island; B, Baffin Island; V, Victoria Island.
2,3 , and 5 are cirque outlet glaciers; and glaciers 6-21 are piedmont lobes from plateau ice caps.

\section{OBSERVATIONS ON THE GLACIERS OF PHILLIPS INLET}

Debris distribution within glacier ice

Debris is present within the terminal ice cliffs as: (1) debris-poor folia which are dispersed throughout the glaciers and express internal flow patterns; (2) debris-rich bands of varying thickness; and (3) debris clots or augens which are of ten smeared or folded (Fig. 2). The debris-poor folia, with occasional discontinuous debris-rich bands, probably represent the diffused englacial zone in Lawson's (1979, p. 6) model. Lawson interpreted the debris-poor folia as aeolian in origin. Further comparison with Lawson's model, notably the two-fold sub-divisions of both his englacial and basal facies, are considered inappropriate for the field area because they are not readily identifiable.

In addition to occurring predominantly in basal ice facies, the debris-rich bands of ten cut across folia, become less abundant both with height at the snout and up-glacier, are irregularly spaced, and contain gravels, sands, and silts in varying concentrations (Fig. 3). Coarser debris-rich bands rarely extend $>1 \mathrm{~m}$ horizontally and many can be traced laterally to gravel terraces deposited on stagnant ice or ice steps (Fig. 4; see below).

Augens occur at many levels in the ice but again are largely concentrated near the base (Fig. 5). Augens contain a variety of sediment ranging from coarse angular debris to fine sands and silts. The degree of sorting varies considerably. The augens do not display a consistent internal structure and contain approximately $<10 \%$ ice by volume. Material from augens and debris-rich bands has been observed slumping or falling out of the ice face and in some cases the material has been completely removed from the glacier.

Apron entrainment (Shaw, 1977a) is immediately apparent where distinct ice blocks, containing dispersed debris, occur in the basal ice zone (Fig. 6). These dry-calved ice blocks originally constituted an apron at the

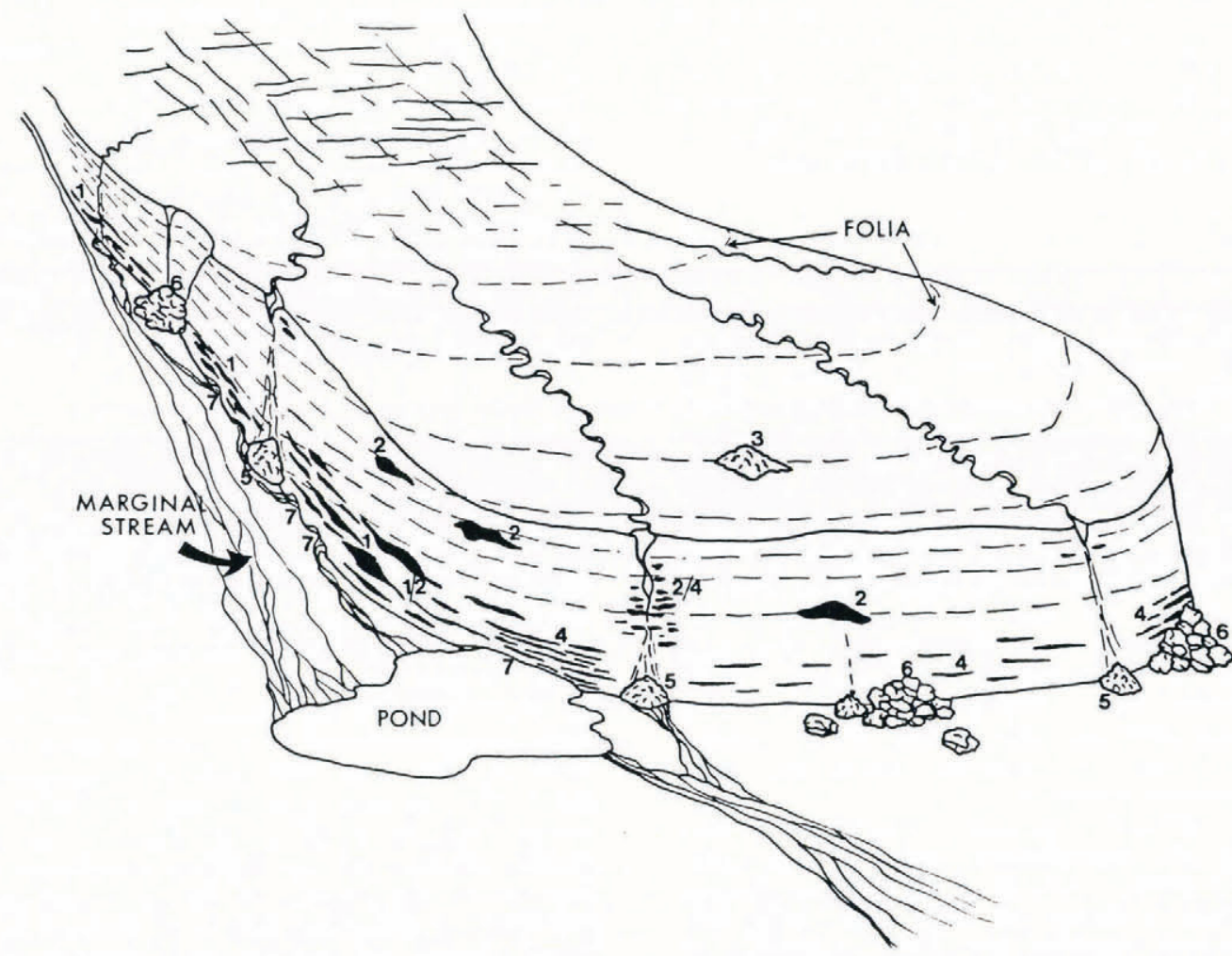

Fig. 2. Idealized sketch of a piedmont lobe with no pro-glacial thrusting illustrating positions of: 1 marginal debris bands; 2, augens; 3 , supraglacial debris cone; 4, frontal debris bands; 5 , waterfall-debris piles; 6 , calved blocks/aprons; 7, thermo-erosional niches cut by lateral streams and an associated ice-marginal pond. 


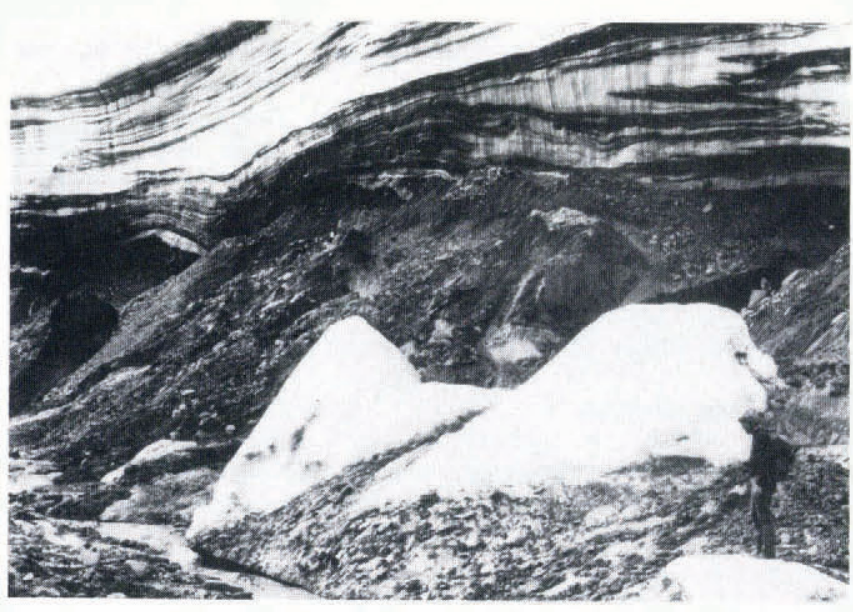

Fig. 3. Debris bands above over-ridden apron at the margin of glacier No. 16. Note how the bands pinch and swell, and are discontinuous. Vertical spacing is also variable but attenuation is greater with height.

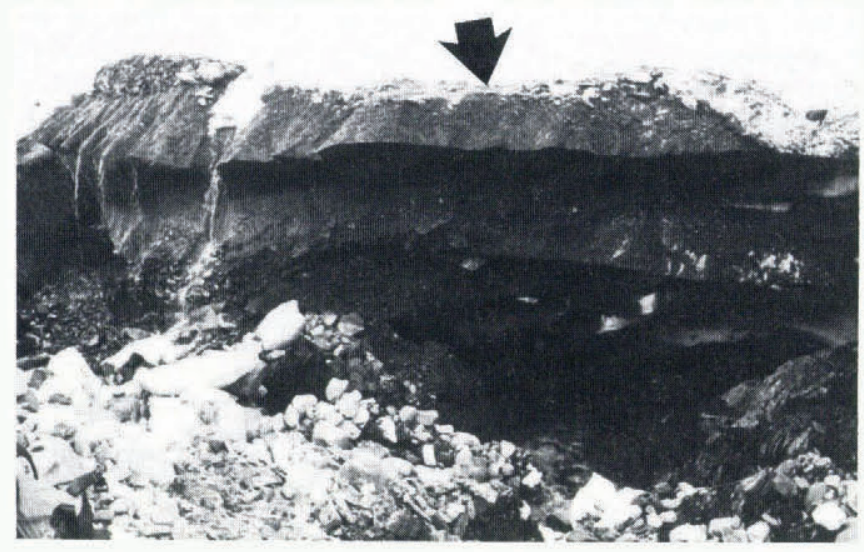

Fig. 4. Gravel bands entrained at the margin of glacier No. 20. Arrow points to gravel terrace approximately $1 \mathrm{~m}$ high deposited on the ice step. Subsequent down-cutting and lateral incision into the glacier was responsible for the deposition of gravel beds at several levels in the ice step and the basal ice. The stream presently penetrates the ice margin to a depth of $>20 \mathrm{~m}$. The collapse of large slabs of ice have buried such ice-cored gravel terraces at various places along the ice margin and fallen blocks have been observed overlying gravel beds entrained within the glacier cliff face.

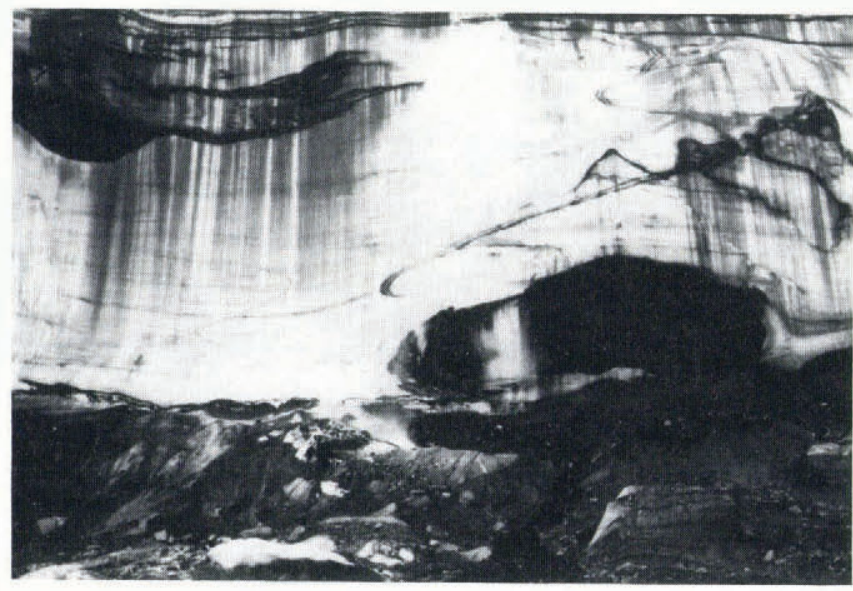

Fig. 5. Augen structures in glacier No. 16, both at the base (clayey silt) and high up (coarse clasts and gravels) in the glacier snout.

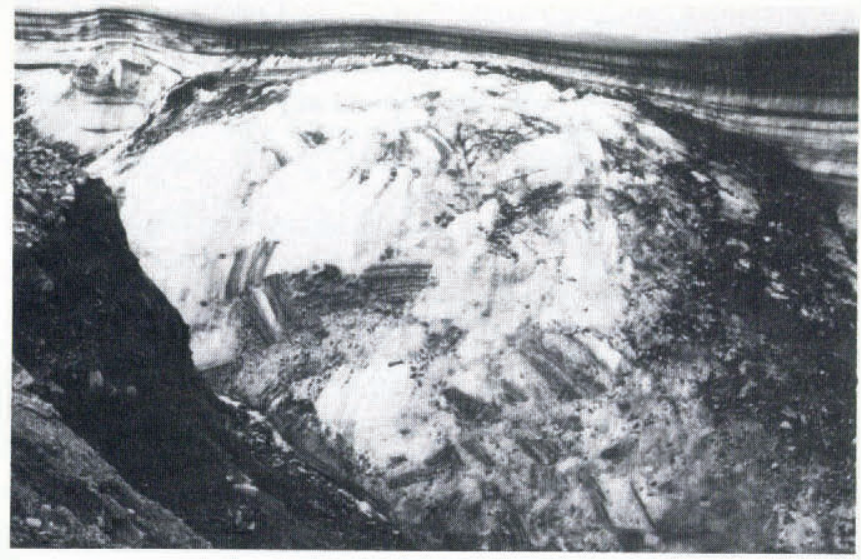

Fig. 6. Re-entrained ice blocks at the base of glacier No. 16. Note debris band at junction of ice blocks and over-riding ice.

snout which has been over-ridden and re-entrained. Above these re-entrained aprons, at the junction of the over-riding ice, debris bands contain a variety of grain-sizes, including cobbles and large sub-angular clasts.

At the bases of glaciers $6,13,16$, and 18, large blocks of alluvium and glacimarine sediment (deposited during the last period of higher sea-level) are incorporated. Below these entrained blocks, over-ridden ice-block aprons can of ten be identified (Fig. 7). The amount of internal disturbance of the sediment within the blocks varies. This is probably the result of flow perturbations in the basal debris-rich ice, resulting in intense folding in some places. Folding at the base of the Barnes Ice Cap has been explained by flow over an irregular substrate (Hudleston, 1976). Therefore, because some of the glaciers of the field area are advancing and over-riding thrust-block moraines (Evans and England, in press), an irregular substrate may explain folding within the basal debris-rich ice.

Basal ice, observed in the cliffed margins, becomes sharply debris-poor up-glacier and coarse debris terminates well below the long-term ELA. At the outer margins of many glacier snouts, single narrow zones within the ice, characterized by large concentrations of all the above debris distributions, have been attenuated and brought to the glacier surface by compressive flow. These bands begin up to $1 \mathrm{~km}$ up-glacier of the snout cliffs and likely represent a single entrainment event or a narrow source area at the glacier bed in the outer margins of the snout.

\section{Contemporary pro-glacial processes}

Fluvial activity has been recognized as a dominant transport mechanism in high-latitude ice-marginal environments (Maag, 1969; Selby, 1973). Therefore, aprons

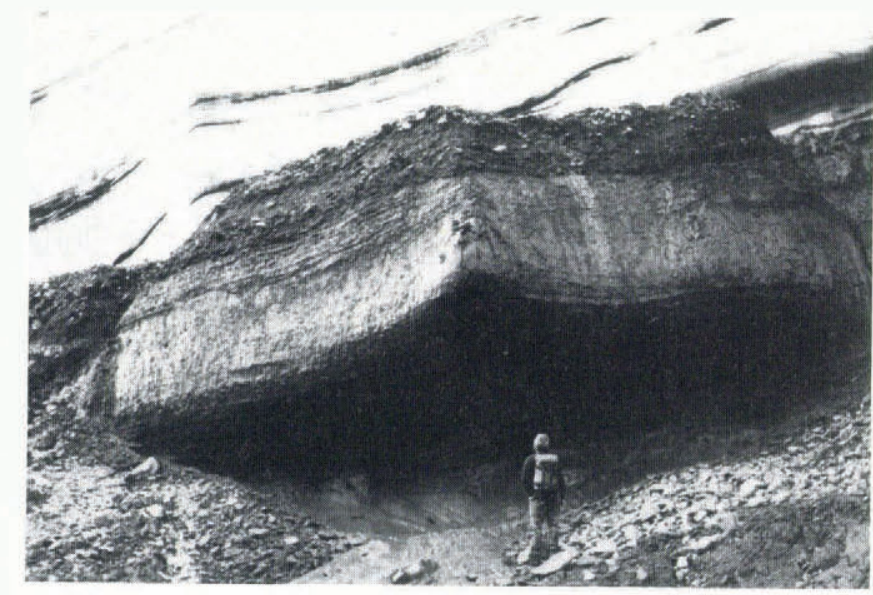

Fig. 7. Thrust slice of marine silt, including shells in life position, at the base of glacier No. 16. A lens of cobbles overlies the silt and likely represents former outwash. The slice overlies a re-incorporated apron of calved ice blocks and debris (see Fig. 10). 
in mountainous polar environments, such as north-west Ellesmere Island, are predominantly composed of alluvium. Because melt water deposits much material close to the glacier margins, it clearly plays a major role in the amount of debris entrained by subsequent glacier advance over aprons.

The most active processes observed at the glacier margins in Phillips Inlet were fluvial. High summer discharges in marginal streams result in large concentrations of lateral fluviglacial debris and pro-glacial fans. These streams have been observed cutting into the glacier margins and disappearing for up to $20 \mathrm{~m}$ before exiting again (Fig. 4). This undercutting leads to ice-block detachment from the glacier and apron accumulation, causing migration of pro-glacial melt-water channels. It is apparent that lateral incision by melt-water streams at the base of the ice margin cuts an ice step over which the stream can migrate. This ice step can be buried by later stream aggradation or further down-cut during stream degradation (Figs 4 and 8). Where a part of the ice step or stream bed represents a short-lived plunge pool or slack-water section, an ephemeral pond may collect sediment. Such ponds were observed at the snouts of glaciers 18 and 20 where they had cut thermo-erosional niches into the snout cliffs. Providing that these ponds are large enough, pockets of sands and silts may collect. Subsequent to the drainage of these ponds, fluvial incision and melt-out of buried ice leads to topographic reversal and creates ice-cored sand/silt cones or drapes. Protection of underlying ice is afforded by the bed load of abandoned marginal streams (Fig. 4). Ice-cored debris mounds also result from abandoned waterfall debris (at the margins of glaciers with considerable supraglacial debris), slumped augen structures, and the sliding of supraglacial debris on to ice steps. Ice steps are diagnostic features of advancing glaciers with proximal marginal melt-water channels and they are constantly buried by dry calving.

Pro-glacial alluvium may also bury and protect stagnant glacial ice as large amounts of melt water are produced during glacier retreat. Stagnant ice buried beneath glacifluvial outwash is evident beyond the snouts of glaciers $2,3,7,9,10,11,1215,18$, and 21 . It would take a considerable climatic change to melt this buried ice, because north-west Ellesmere Island is in the zone of continuous permafrost where the active layer is $<1 \mathrm{~m}$ thick.

\section{Clast-shape analysis}

In order to understand any possible relationships between pro-glacial processes and glacial entrainment, a total of 18 samples of 50 clasts was taken from basal debris-rich ice within glaciers 6,20 , and 21 , and from material immediately adjacent to these glaciers. Measurements of clast shape are of importance to the interpretation of glacier-bed conditions. For example, stoss-and-lee forms suggest active lodgement processes (Boulton, 1978; Sharp, 1982). Successive episodes of melting and regelation at the glacier bed (increased clast/bed contacts) tend to lead to greater rounding and less sphericity. Boulton (1978) further suggested that there is also an increase in blades and discs, and multiple striations. However, Humlum (1981) and Dowdeswell and others (1985) provided statistics that indicate a predominance of spheres in clast populations that have undergone considerable glacial transport and wear. Comparisons of clast shape and roundness are most appropriate within single drainage basins, because clast lithology may affect both parameters considerably. In a geologically variable area like northern Ellesmere Island (Trettin, 1987), comparisons between drainage basins are inadvisable.

Here, comparisons are made between clasts $(>4 \mathrm{~cm}$
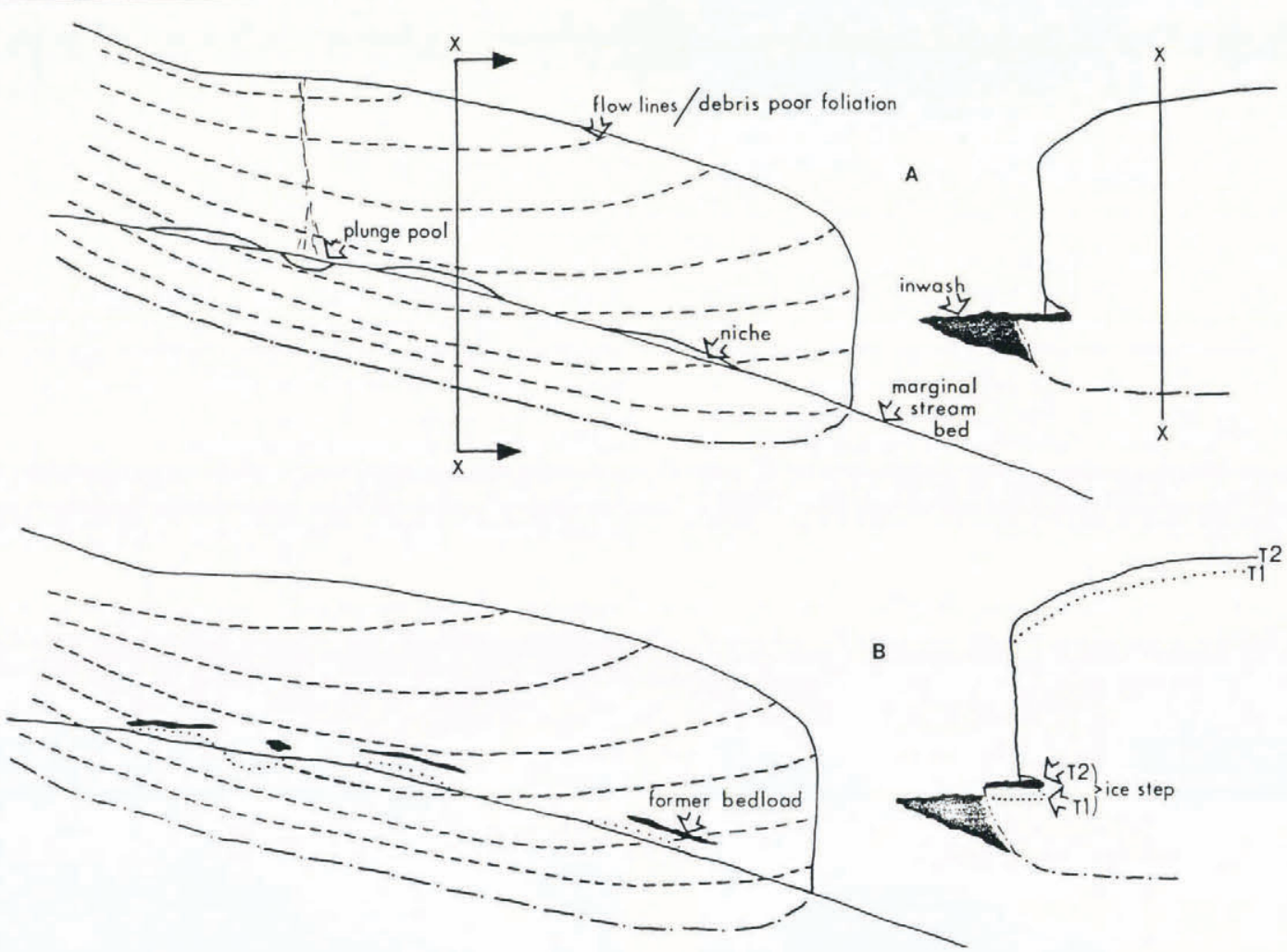

Fig. 8. Simpified time-sequence diagram of lateral entrainment of marginal stream bed load. " $A$ " is at the end of a period of negative mass balance whence the stream has excavated three thermo-erosional niches/scour pools and a waterfall has excavated a plunge pool. Glacier ice extends below the stream-bed level because of the cutting of an ice step by lateral stream erosion. " $B$ " is at the end of a period of positive mass balance. Ice flow within the snout has displaced the bed load (deposited in the scour pools in the ice face) upward from the stream-bed level and down-glacier. Note that the the scour pools in the ice face) upward from the stream-bed level and down-glacier. Nocilited by dry calving if undercutting by the stream leads to slab failure of the ice cliff. The positions of the niches and plunge pools at the end of the previous negative mass-balance period are shown by the dotted line in " $B$ ". 
diameter) from within the glacier snouts (nine samples) and those from ice-proximal or ice-contact material (nine samples). Eleven of these samples were collected from within and around the snout of glacier 20 and their shape analyses reveal a marked similarity between stones from the two environments (Fig. 9). Of the remaining seven samples,

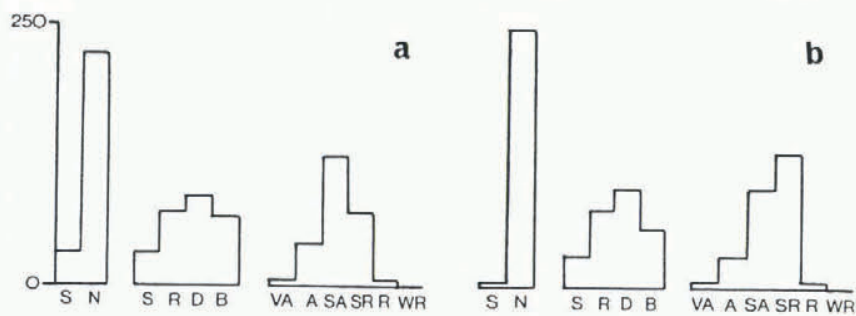

Fig. 9. Histograms of clast-shape analyses from glacier 20. (a) (five samples) is from basal glacier ice and (b) (six samples) is from marginal sediments. Abbrevations are from left to right: $S$, striated; $N$, non-striated: $S$, spheres; $R$, rods; $D$, discs; $B$, blades; $V A$, very angular; $A$, angular. $S A$, sub-angular; $S R$, sub-rounded, $R$, rounded; WR, well rounded (Zingg, 1935; Powers, 1953).

three were from within and around glacier 21 and four from within and around glacier 6. Details of clast-shape analyses are available in Evans (unpublished). At the snout fronts there is considerable similarity in stone shapes between debris cones on stagnant ice, debris cones on the glacier surface, and entrained debris. Along the glacier margins there are striking similarities between samples from ice-marginal fluvial material, partially entrained or over-ridden gravel terraces, and gravel lenses in basal ice.

Of the 900 clasts measured in the field, $130(14 \%)$ had striations and $24(3 \%)$ had stoss-and-lee forms. Of these, only $39(4 \%)$ and five $(0.5 \%)$, respectively, were directly from the glacier snouts. Hence, $83 \%$ of the clasts measured showed no direct evidence of glacial modification. Multiple striations were noted on only six $(0.5 \%)$ clasts, one being from a glacier snout. No significant increase in blades and discs was observed between ice-marginal and entrained debris. The sphere was the least-represented shape in all samples from glacier ice and, according to Humlum (1981) and Dowdeswell and others (1985), this indicates that clasts have undergone very little wear. Moreover, all of the clast data suggests that material undergoes little modification during entrainment and transport, and successive episodes of melting and regelation at the glacier bed are unlikely. Therefore, it appears that apron entrainment is the most dominant debris-incorporation process in the Phillips Inlet glaciers.

\section{DISCUSSION}

\section{Debris-rich bands}

Coarse debris-rich bands at the lateral margins of the Phillips Inlet glaciers are interpreted as the re-entrained bed load of ice-marginal streams because: (1) the sediments are of ten stratified sands and gravels which grade laterally into ice-cored terraces; (2) the bands pinch and swell along their lengths; (3) they disappear up-glacier; (4) they are concentrated in the basal ice layers; (5) they are irregularly spaced, both vertically and horizontally; (6) they rarely extend >1 m laterally; (7) they cut across folia at the snout; and (8) their clast shapes show a striking similarity to pro-glacial material. Therefore, the bands do not represent cross-sections of continuous debris frozen on at the glacier bed and carried to the outer margins by flow. The reentrainment of pro-glacial sediment may involve an annual cycle caused by melt-water incision into the ice face during the summer followed by freeze-up and incorporation during the winter (cf. Harris and Bothamley, 1984). Large concentrations of debris may represent meander bends, abandoned terraces, ephemeral pools, or waterfall-debris piles. Alternatively, when considering glaciers with low activitiy indices, these large concentrations could represent several years of accumulation along a stable ice margin and may not be annual deposits.
If there is a net increment of fluvial, rock-fall, or other extraglacial debris, then morainic mounds will build up at the ice margin. These are composed largely of sands and gravels but are essentially alluvial fans with a variable colluvial component. At the margins of many of the Phillips Inlet glaciers, ice steps, shallow ice surfaces, and stagnant ice are covered by a veneer of alluvium. This protects the ice from sublimation and melt, and is a potential source of ice-cored mounds for re-entrainment during any future glacial advance (Fig. 10).

\section{Augens or debris clots}

There appear to be at least four alternative origins for the augen structures observed in the basal ice at glacier margins in Phillips Inlet. First, the augens represent accumulations within the meander bends of marginal streams. These meanders of ten cut back into the ice cliff and debris is deposited in the resulting hollows and niches (Fig. 8). Augens originating from these sources would likely consist of poorly sorted gravels and sands.

Secondly, where ponds cut thermo-erosional niches into the snouts of glaciers, large pockets of fine-grained sediments can collect and be incorporated during glacier advance. Largely undisturbed deltaic sediments have been observed in englacial positions by Harris and Bothamly (1984). They interpreted this as material frozen on to the glacier sole by winter cooling through thin marginal ice. The sediments accumulated originally in a subglacial pool during a period of ice recession.

Thirdly, the augens represent re-entrained ice-cored mounds and alluvium-covered stagnant ice. Ice-cored mounds originate at the ice margin or on ice steps where the sediments from abandoned streams, drained or frozen ponds (silt/sand drapes), slumped supraglacial cones and augens, and waterfall debris accumulate. Figure 10 shows a mode of origin for gravel augens in the face of glacier 21 . A large cave at the snout of glacier 21 revealed "clean" ice with debris-poor folia directly overlying bedrock. Elsewhere the snout has advanced on to gravel terraces which were deposited over stagnant ice during a period of glacier recession. Subsequent over-riding of these ice-cored terraces has led to the incorporation of three augens, approximately $5 \mathrm{~m}$ in diameter, in the snout cliff (Fig. 10). The occurrence of such augens in a glacier snout clearly reflects climatic change through glacier re-advance.

Fourthly, augens of fine-grained material within glacier snouts may be explained by glacier advance into areas of thick, deformable, and frozen sediment. Figure 11 provides an explanation for the occurrence of thrust slices in the basal debris-rich ice of glacier 16 (Fig. 7). Pro-glacial thrusting is initiated in thick deformable materials, such as outwash and glacimarine sediments, by some piedmont-lobe glaciers (Kalin, 1971; Evans and England, in press). The detachment of slices of material and their thrusting over marginal aprons may explain the inclusion of largely undeformed frozen sediments in the basal ice. The attenuation of such slices may explain some fine-grained augens and debris bands within the frontal cliffs of glaciers. This pro-glacial thrusting and over-riding represents an alternative process for introducing frozen, unlithified clasts to basal ice than that proposed by Boulton (1979), Moran and others (1980), and Shaw (1982).

\section{Holocene glacier fluctuations}

The single entrainment event represented by the narrow zones of concentrated debris-rich bands and augens in some glacier-snout margins most probably occurred when glaciers were up to $1 \mathrm{~km}$ behind their present positions. Because much of the debris entrained during this event originated as ice-contact alluvium, it therefore represents increased fluvial activity during a period of glacier recession. As is illustrated in Figures 8 and 10, a prolonged ablation period resulted in glacier thinning and large tracts of alluviumcovered stagnant ice. Over-riding of the alluvium during recent glacier advance occasioned the re-activation of the stagnant ice and the incorporation and compressive deformation of debris-rich ice (former alluvium; Fig. 10).

Corroborative evidence for such a re-advance by the larger piedmont-lobe glaciers is provided by radiocarbon dates on marine shells associated with over-ridden marine and deltaic sediments. The snout of glacier 16 contains 
1
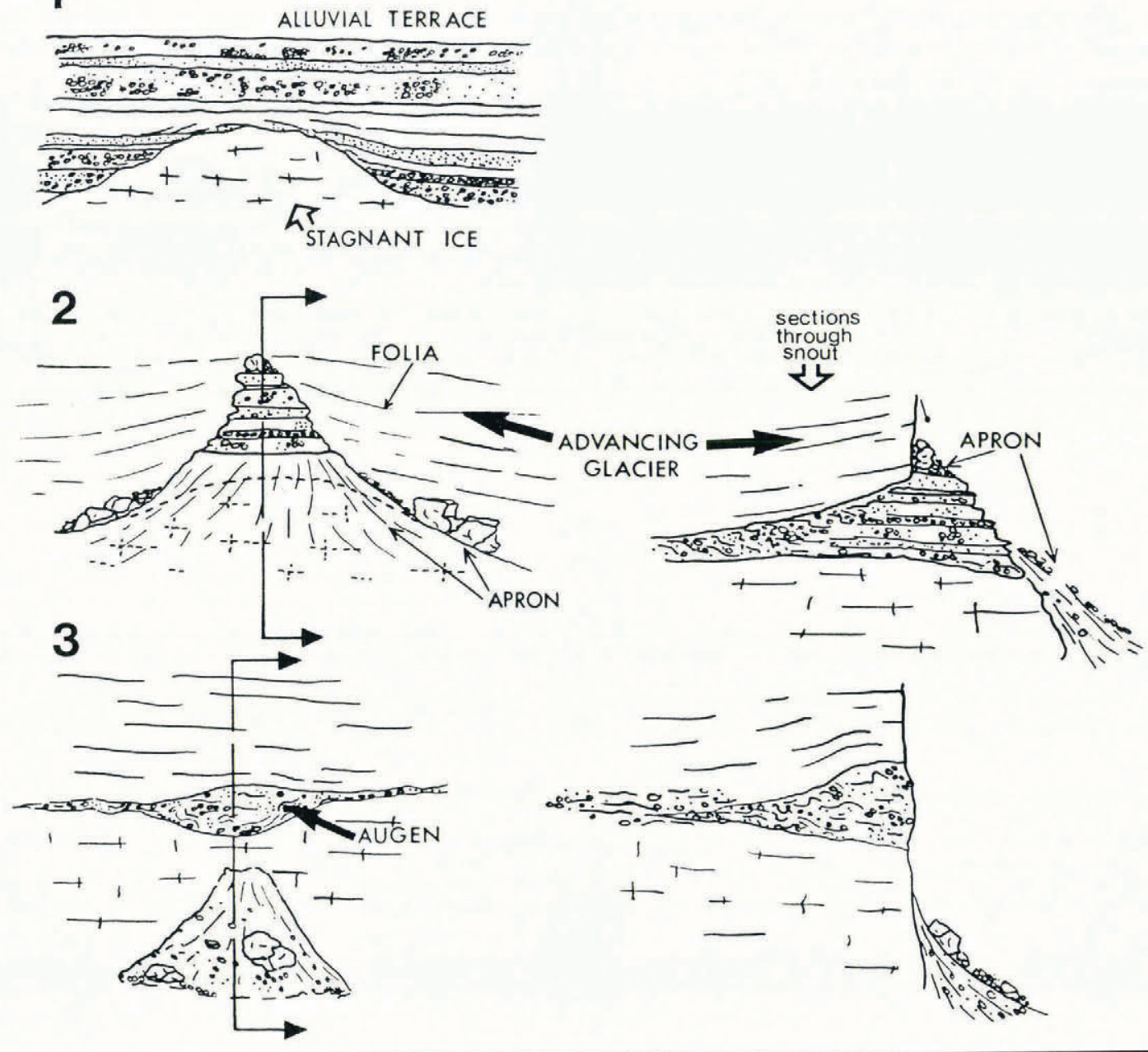

Fig. 10. An explanation for the origin of gravel augens in the face of glacier No. 21. 1. Glacier retreat results in the progradation of alluvium over stagnant ice. Because of the shallow active layer. the ice does not melt. 2. Climatic deterioration results in glacier re-advance and the over-riding of the ice-cored alluvium. The alluvium is deformed and reworked as an apron. 3. Complete entrainment results in augen which marks the boundary between older, formerly stagnant ice and over-riding glacier ice. The size of augen is dictated by the amount of retrogressive thaw and slumping of the ice-cored terrace before and during incorporation. Further advance results in recycling of augen gravels in aprons.

thrust and incorporated slices of raised marine silts including Hiatella arctica shells in life position that date at $5200 \pm 60$ B.P. (TO 472). Glacier 20 is presently over-riding a raised delta including Hiatella arctica shells dating $8710 \pm 70$ B.P. (TO 848). Because initial deglaciation occurred throughout Phillips Inlet between $10140 \pm 90$ (TO 473) and $7820 \pm 70$ B.P. (TO 255), the above shell dates provide unequivocal evidence that some glaciers are at their post-glacial maximum positions (cf. Evans, unpublished). Several studies have cited evidence of a marked warm period during the early Holocene which resulted in a pronounced calving phase and rapid glacier retreat on northernmost Ellesmere Island (Koerner and Fisher, 1985; Bednarski, 1986; Evans, unpublished; Stewart, unpublished). This warm period was terminated between 4000 and 3000 B.P. (mid-Holocene climatic deterioration) when Ellesmere Island ice shelves formed (Stewart and England, 1983). Because of their slower response rates, the larger glaciers of the region are still advancing as a result of increased accumulation during the mid-Holocene. Therefore, the narrow zone of debris concentrations in some snouts may have originated as alluvium-covered stagnant ice during the early Holocene. Re-incorporation was initiated during the mid-Holocene and attenuation and recycling continues today (Fig. 10).

\section{CONCLUSIONS}

Changes in basal thermal regime through time are responsible for the entrainment of large amounts of debris and regelation ice (Weertman, 1961; Boulton, 1972b), and subglacial rafts (Moran and others, 1980). Deceleration of ice movement and compressive flow in the snout zone would then bring debris-charged folia to the glacier surface. However, in many of the Phillips Inlet glaciers debris entrained within folia at the snout is negligible and this contrasts markedly with lateral margins where concentrations of debris appear largely independent of flow lines or folia (Figs 2 and 8). Therefore, the basal freeze-on mechanism is not as important to debris entrainment in the Phillips Inlet glaciers as it is to glaciers in maritime Arctic locations (Boulton, 1970; Dowdeswell, 1986). The identification of regelation ice (unequivocal evidence of melting and refreezing at the glacier bed) has been undertaken in other areas on large glacier systems (cf. Lawson, 1979; Boulton and Spring, 1986) but this still needs to be addressed in the High Arctic.

Debris entrainment by the process of apron entrainment (Shaw, 1977b) and the over-riding and incorporation of stagnant ice (Hooke, 1973) are recongized at the margins of the Phillips Inlet glaciers. Apron entrainment by the Phillips Inlet glaciers is distinct from that identified in Antarctica by Shaw $(1977 a, b)$ in that greater amounts of fluvially derived debris are common in the High Arctic ice aprons. Any prolonged period of glacial retreat will result in the burying of thin ice margins by alluvium and the excavation of subglacial tunnels and their filling by fluvial sediment (Fig. 4). Glacial re-advance results in incorporation of such alluvium-dominated aprons at the margins and the front of the snout. 

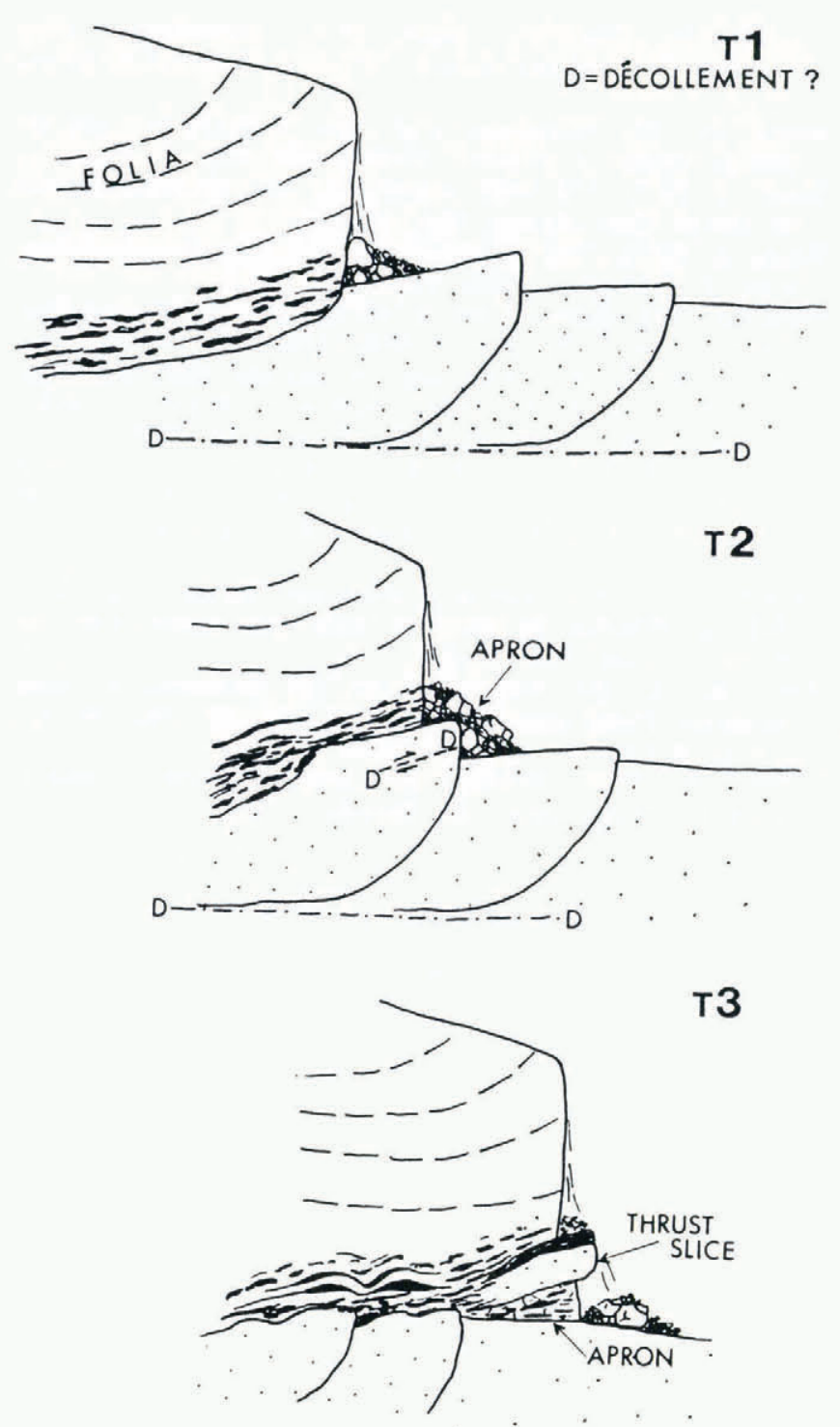

Fig. 11. A possible explanation for the occurrence of thrust slices in the basal debris-rich ice of glacier No. 16 (Fig. 7a). T1. Climatic deterioration results in re-advance by glacier on to Holocene raised marine sediments deposited during the last deglaciation. The glacier thrusts the marine sediments which fall along an unidentified décollement plane. T2. Over-riding of the thrust blocks by the glacier initiates seondary decollement and results in the deposition of aprons. T3. Complete over-riding of the thrust blocks detaches a raft of marine sediment which now marks the boundary of basal debris-rich ice (former apron) and the upper glacier ice. Further advance results in attenuation of entrained sediments.

The large concentrations of debris which are characteristic of many of the glacier snouts in Phillips Inlet may relate to the over-riding and incorporation of large tracts of stagnant ice during the mid-Holocene climatic deterioration (Stewart and England, 1983; Koerner and Fisher, 1985). Radiocarbon dates and clast-shape analyses suggest that raised marine sediments deposited behind present glacier margins during the early Holocene have been incorporated and passively transported by local glaciers. Single narrow zones of re-entrained debris, which have been deformed, attenuated, and brought to the glacier surface by compressive flow, suggest that some glaciers may have re-advanced up to $1 \mathrm{~km}$ since the early Holocene climatic optimum (Stewart and England, 1983). These observations suggest that previously documented glacial debris entrainment processes, involving complex basal thermal regimes and internal thrusting, are only of secondary importance in some high-latitude glacier snouts.

\section{ACKNOWLEDGEMENTS}

Logistical support for the 1985-87 field seasons was provided by the Polar Continental Shelf Project, Department of Energy, Mines and Resources Canada, Ottawa. Financial support was provided by the Boreal Institute for Northern Studies, University of Alberta. NSERC grant No. A6680 awarded to $\mathrm{Dr}$ J.H. England is gratefully acknowledged. T. Fisher and U. Hawkins were able field assistants from 1985 to 1987. Helpful comments on the paper have been made by my colleagues J. England, T. Bell, D.S. Lemmen, T.G. Stewart, and R.B. Rains, and two anonymous referees. Many thanks are due to W.A. and J.M. Evans for office and computing facilities.

\section{REFERENCES}

Ahlmann, H.W. 1935. Contribution to the physics of glaciers. Geogr. J., 86(2), 97-113.

Bednarski, J. 1986. Late Quaternary glacial and sea-level events, Clements Markham Inlet, northern Ellesmere Island, Arctic Canada. Can. J. Earth Sci., 23(9), 1343-1355.

Boulton, G.S. 1970. On the origin and transport of englacial debris in Svalbard glaciers. J. Glaciol., 9(56), 213-229.

Boulton, G.S. 1972a. Modern Arctic glaciers as depositional models for former ice sheets. J. Geol. Soc., London, 128(4), 361-393.

Boulton, G.S. 1972b. The role of thermal régime in glacial sedimentation. In Price, R.J. and D.E. Sugden, comps. Polar geomorphology. London, Institute of British Geographers, 1-19. (Special Bulletin 4.)

Boulton, G.S. 1978. Boulder shapes and grain size distributions of debris as indicators of transport paths through a glacier and till genesis. Sedimentology, 25, 773-799.

Boulton, G.S. 1979. Processes of glacier erosion on different substrata. J. Glaciol., 23(89), 15-38.

Boulton, G.S. and U. Spring. 1986. Isotopic fractionation at the base of polar and sub-polar glaciers. J. Glaciol., 32(112), 475-485.

Bovis, M.J. and R.G. Barry. 1974. A climatological analysis of north polar desert areas. In Smiley, T.L. and J.H. Zumberge, eds. Polar deserts and modern man. Tucson, AZ, University of Arizona Press, 23-31.

Dowdeswell, J.A. 1986. The distribution and character of sediments in a tidewater glacier, southern Baffin Island, N.W.T., Canada. Arct. Alp. Res., 18(1), 45-56.

Dowdeswell, J.A., M.J. Hambrey, and R. Wu. 1985. A comparison of clast fabric and shape in Late Precambrian and modern glacigenic sediments. J. Sediment. Petrol., 55(5), 691-704.

England, J.H., L. Kershaw, C. LaFarge-England, and J. Bednarski. 1981. Northern Ellesmere Island: a natural resource inventory. Edmonton, University of Alberta. Department of Geography. (Report to Parks Canada.)

Evans, D.J.A. Unpublished. Glacial geomorphology and Late Quaternary history of Phillips Inlet and the Wootton Peninsula, northwest Ellesmere Island, Canada. (Ph.D. thesis, University of Alberta, 1988.)

Evans, D.J.A. and J.H. England. In press. Canadian landform examples: thrust block moraines of the Canadian high Arctic. Can. Geogr.

Hambrey, M.J. and F. Müller. 1978. Structures and ice deformation in the White Glacier, Axel Heiberg Island, Northwest Territories, Canada. J. Glaciol., 20(82), 41-66.

Harris, C. and K. Bothamley. 1984. Englacial deltaic sediments as evidence for basal freezing and marginal shearing, Leirbreen, southern Norway. J. Glaciol., 30(104), 30-34.

Hooke, R.LeB. 1973. Flow near the margin of the Barnes Ice Cap, and the development of ice-cored moraines. Geol. Soc. Am. Bull., 84(12), 3929-3948.

Hudleston, P.J. 1976. Recumbent folding in the base of the Barnes Ice Cap, Baffin Island, Northwest Territories, Canada. Geol. Soc. Am. Bull., 87(12), 1648-1692.

Humlum, O. 1981. Observations on debris in the basal transport zone of Mýrdalsjökull, Iceland. Ann. Glaciol., 2, 71-77. 
Kälin, M. 1971. The active push moraine of the Thompson Glacier, Axel Heiberg Island. Canadian Arctic Archipelago. Axel Heiberg Isl. Res. Rep. McGill Univ. Glaciol. 4.

Koerner, R.M. and D.A. Fisher. 1985. The Devon Island ice core and the glacial record. In Andrews, J.T., ed. Ouaternary environments: eastern Canadian Arctic, Baffin Bay and western Greenland. Boston, MA, etc., Allen and Unwin, 309-327.

Lawson, D.E. 1979. Sedimentological analysis of the western terminus region of the Matanuska Glacier, Alaska. CRREL Rep. 79-9.

Maag, H. 1969. Ice dammed lakes and marginal glacial drainage on Axel Heiberg Island, Canadian Arctic Archipelago. Axel Heiberg Isl. Res. Rep. McGill Univ.

Moran, S.R., L. Clayton, R.LeB. Hooke, M.M. Fenton, and L.D. Andriashek. 1980. Glacier-bed landforms of the prairie region of North America. J. Glaciol., 25(93), 457-476.

Paterson, W.S.B. 1981. The physics of glaciers. Second edition. Oxford, etc., Pergamon Press.

Powers, M. 1953. A new roundness scale for sedimentary particles. J. Sediment. Petrol., 25, 117-119.

Selby, M.J. 1973. The termini and moraines of glaciers in the McMurdo dry valleys, Antarctica. In Stokes, E., ed. Proceedings of the Seventh New Zealand Geography
Conference, Hamilton, August 1972. Christchurch, New Zealand Geographical Society, 247-257. (Conference Series 7.)

Sharp, M. 1982. Modification of clasts in lodgement tills by glacial erosion. J. Glaciol., 28(100), 475-481.

Shaw, J. 1977a. Till body morphology and structure related to glacier flow. Boreas, 6(2), 189-201.

Shaw, J. 1977b. Tills deposited in arid polar environments. Can. J. Earth Sci., 14(6), 1239-1245.

Shaw, J. 1982. Melt-out till in the Edmonton area, Alberta, Canada. Can. J. Earth Sci., 19(8), 1548-1569.

Stewart, T.G. Unpublished. Deglacial marine sediments from Clements Markham Inlet, Ellesmere Island, N.W.T., Canada. (Ph.D. thesis, University of Alberta, 1988.)

Stewart, T.G. and J.H. England. 1983. Holocene sea-ice variations and paleoenvironmental change, northernmost Ellesmere Island, N.W.T., Canada. Arct. Alp. Res., 15(1), $1-17$.

Trettin, H.P. 1987. Pearya: a composite terrane with Caledonian affinities in northern Ellesmere Island. Can. J. Earth Sci., 24(2), 224-245.

Weertman, J. 1961. Mechanism for the formation of inner moraines found near the edge of cold ice caps and ice sheets. J. Glaciol., 3(30), 965-978.

Zingg, T. 1935. Beitrag zur Schotteranalyse. Schweiz. Mineral. Petrogr. Mitt., 15, 38-140. 